\title{
Exploring the Relationships Between High School Course Enrollment, Achievement, and First-Semester College GPA
}

\author{
Jeffrey M. Warren \\ University of North Carolina at Pembroke \\ Camille L. Goins \\ University of North Carolina at Pembroke
}

\begin{abstract}
This study explored the impact of Advanced Placement and honors course enrollment and high school grade point average (GPA) on first-semester college GPA. Data were collected from 131 college freshmen enrolled at a minority-serving institution who graduated from a public school during the previous academic year. A four-step hierarchical multiple regression analysis indicated that family structure, college status, enrollment in one or more Advanced Placement courses, and enrollment in five or more honors courses accounted for a significant amount of variance explained in first-semester college GPA, both individually and in combination. High school GPA intervened in these variables relationships with firstsemester college GPA accounting for a significant amount of variance. Based on these findings, opportunities for future research and implications for K-12 schools and colleges are provided.
\end{abstract}

Keywords: AP courses, honors courses, high school GPA, college GPA, family structure

\section{Introduction}

In response to K-12 public education reform in the United States, schools now place greater emphasis on preparing college and career-ready (CCR) students. The Common Core Standards (CCS) implemented across the nation reflect CCR expectations deemed necessary for postsecondary success. A further attempt to strengthen K-12 education, the Every Student Succeeds Act (U.S. Department of Education, 2015), aims to ensure that each state identifies and uses a high-quality assessment system that promotes equity and measures student progress toward CCR. Measures of CCR vary across the nation but often include high school grade point average (GPA), English language arts and mathematics assessment via the SAT or ACT, the ACT College Readiness Assessment, and the ACT WorkKeys Assessment. Students who meet the designated state requirements are considered CCR, graduate from high school, and pursue a host of postsecondary options including entering college or the workforce.

The perceptions of postsecondary preparation differ among K-12 educators and college instructors. (ACT, 2016; Holles, 2016; Reed \& Justice, 2014). ACT (2016) reported that 42\% of K-12 educators believe that the CCS are aligned with college expectations; $16 \%$ of college instructors believe students entering college are well prepared for college-level coursework, a decrease from 2012 of $26 \%$. Employers concur that there are gaps between the knowledge and skills acquired during K-12 education and those necessary for success in the workplace (Castellano, Sundell, Overman, Richardson, \& Stone, 2014; Rothwell, 2016). For example, between $40 \%$ and $60 \%$ of students are required to take noncredit-bearing remedial courses in reading and math during their first year of college; many of these students are underprepared and fail to complete their program of study (Castellano et al., 2014; Jimenez, Morales, Sargrad, \& Thompson, 2016). 
As K-12 public schools across the nation implement the Every Student Succeeds Act along with the CCS and subsequent programs of study, there is an opportunity to increase CCR by providing all students access to a rigorous curriculum that fosters real-world connection and prepares students for postsecondary success (Goins, 2016). Rigorous high school courses such as Advanced Placement (AP), dual enrollment, honors, and technical courses can prepare students for college and the workforce (Barnett, 2018; Brand, Browning, \& Valent, 2013; Lewis, Kosine, \& Overman, 2008; Meeder \& Suddreth, 2012). Furthermore, research findings suggest that students who complete programs of study that include these types of courses are better positioned for postsecondary success (Castellano et al., 2014; Floyd, 2014; Goins, 2016; Mould \& DeLoach, 2017). In the current study, researchers explored the manner in which honors courses, AP courses, and high school GPA predict firstsemester college GPA. All students should have an opportunity to engage in rigorous coursework; this should remain a priority among educational institutions (Barnett, 2018; Theokas \& Saaris, 2013; U.S. Department of Education, Office of Planning, Evaluation and Policy Development Policy and Program Studies, 2017; U.S. Department of Education, Office of Vocational and Adult Education, 2012).

\section{Honors Courses}

According to Woods, Park, Hu, and Betrand Jones (2018), enrollment in honors courses during high school allows students to complete a rigorous course load that provides better preparation for college. Honors courses require students to exceed the expectations set for mastering the standards of the general curriculum through higher level coursework centered on solving real-world problems. Enrollment in honors courses can strengthen high school GPA for students who perform well. Klopfenstein and Lively (2012) and Woods et al. (2018) have suggested that college-level coursework such as honors courses is beneficial to students who are on target to become CCR. However, for students who are struggling, increasing rigor without the proper support services can lead to frustration and failure. Therefore, to better prepare students for college-level coursework by their junior year, school systems should increase the rigor of their K-10 curriculum (Klopfenstein \& Lively, 2012).

\section{Advanced Placement Courses}

The AP program affords students the opportunity to participate in college-level coursework during high school while earning college credit (College Board, 2018). In addition to providing a rigorous curriculum, AP courses are used as an evaluation method for college acceptance. High school students who successfully complete AP courses often experience a reduction in tuition costs and graduate from college in less than 4 years (Weinstein, 2016).

Enrollment in AP courses has increased over the last decade from 23.9\% to 37.7\%; over 1 million students have completed an AP exam (College Board, 2017). Graduating students who scored a 3 or higher on an AP exam increased from 14.6\% in 2007 to 22.8\% in 2017 (College Board, 2017). This high-quality program is considered the most reliable measure for college readiness and also promotes educational equity (Challenge Success, 2013). However, AP courses are generally offered to academically gifted students; exceptional children and minority students often are underrepresented (Kolluri, 2018).

\section{Purpose of Study}

Across the nation, students enter college lacking the academic and psychosocial skills needed for postsecondary success. In many instances, students graduate from high school with a diploma to indicate college and career readiness; however require remedial coursework prior to taking true credit-bearing courses in college (Castellano et al., 2014). In other cases, students enter the college 
classroom ill prepared for the rigor and expectations of course instructors. It is evident that rigorous high school coursework and subsequent high school GPA are keys to postsecondary success. However, research findings do not clearly articulate the impact these high school factors have on first-semester college GPA.

In this study, we sought to explore the relationships between high school course enrollment, cumulative high school GPA, and first-semester college students' GPA. The following research questions emerged and guided this study: Do rigorous high school coursework and subsequent cumulative GPA relate to first-semester college GPA? What impact do student demographic factors have on first-semester college GPA? These research questions, in conjunction with prior literature, led to the development of the following hypotheses:

Hypothesis 1: High school variables including concentration, the number of honors and AP courses taken, and GPA will positively correlate with first-semester college GPA.

Hypothesis 2: Race/ethnicity, gender, family structure, college status, and urbanicity will correlate with first-semester college GPA.

Hypothesis 3: After race/ethnicity, gender, family structure, college status, and urbanicity are controlled, the number of honors and AP courses taken and high school GPA will positively correlate with first-semester college GPA.

\section{Method}

\section{Participants}

Participants in this study were freshman students $(N=131)$ enrolled at a public minority-serving institution (MSI) in the southeast quadrant of the United States. Of these participants, most identified as African American $(n=50,38.2 \%)$, whereas the remainder identified as White $(n=44$, $34.3 \%)$, American Indian ( $n=16,12.2 \%)$, Hispanic/Latino $(n=13,9.9 \%)$, or Asian $(n=6,4.6 \%)$. One participant identified as Black and White $(0.8 \%)$ while another identified as Pacific Islander and Hispanic (0.8\%). Most participants identified as female $(n=97,74.0 \%)$; the remainder identified as male $(n=34,26.0 \%)$. Of the participants, $52.7 \%(n=69)$ indicated they lived with both biological parents. The rest of the participants lived with one biological parent ( $n=56,42.7 \%)$, aunts and uncles $(n=3,2.3 \%)$, and grandparents $(n=3,2.3 \%)$. Considering level of education, $32.8 \%(n=43)$ of participants had parents who had earned a high school diploma or less, while $25.2 \%(n=33)$ had completed some college. The remainder of participants indicated that their parents had completed a 2 -year degree $(n=22,16.8 \%)$, a 4 -year degree $(n=20,15.3 \%)$, or a master's degree or higher $(n=13$, $9.9 \%)$. Finally, regarding urbanicity, $61.8 \%(n=81)$ of participants graduated from a high school located in a metropolitan area; $38.2 \%(n=50)$ graduated from a rural high school.

\section{Procedures}

We conducted a literature review to explore high school factors that impact college student success. Based on existent literature, a research study was developed to explore the relationship between high school factors and first-semester college GPA. A research application was developed and submitted to the university institutional review board. After approval to conduct the study was received, an email was disseminated five times across 3 weeks to all second semester freshmen students who graduated the prior academic year from a traditional public high school. The email contained a request to participate in the study and a link to a Qualtrics survey that included informed consent, survey items, and a debriefing statement. Out of 858 students who met the criteria for inclusion in the study, 131 participants completed the survey, a response rate of $15.3 \%$. 
All participants who completed the study and provided their email address entered a drawing for a chance to win a gift basket valued over $\$ 100$.

\section{Instruments}

Participants completed a set of demographic questions and a questionnaire developed by the authors. The questions were based on existent literature about high school factors that impact college student success. The demographic form included questions about race/ethnicity, gender, family structure, college status, and high school location. The questionnaire asked participants about their experiences in high school and first semester of college. For example, participants responded to questions such as "How many AP courses did you complete?" and "What is your current freshman GPA?" Students self-reported on courses taken during high school as well as their high school and college GPAs.

\section{Results}

\section{Initial Analyses}

A preliminary analysis was conducted to better understand the participants and factors under investigation. Given a review of existent literature and student body composition at the researchers' university, minority and majority categories were created to organize race/ethnicity. In line with Ivers, Johnson, Clarke, Newsome, and Berry (2016) and Warren and Hale (in press), participants who identified as non-White (i.e., African American, American Indian, Hispanic/Latino, and Asian) were classified as racial/ethnic minority; White participants were considered racial/ethnic majority. Family structure comprised traditional and nontraditional. Traditional was defined as an intact family unit (i.e., biological mother and father), whereas nontraditional included any family make-up other than an intact family unit (e.g., lived with mother and step-father, grandparents, or uncle). College status included participants' parents' education level. In this study, participants were considered continuing-generation college students (CGCS) if their parents earned an associate degree or higher. First-generation college students (FGCS) were those whose parents completed some college or less. Finally, urbanicity described high school location, either metropolitan or nonmetropolitan. Using the Rural-Urban Continuum Codes (U.S. Department of Agriculture, 2013), metropolitan areas ranged from those counties with populations under 250,000 to those with over 1 million. Nonmetropolitan encompassed counties with a population less than 2,500 and not adjacent to a metropolitan county to a population of 20,000 or more and adjacent to a metropolitan area. Table 1 provides means, standard deviations, and ranges for these demographic variables. The $p$ values denoting significant differences in college GPA by demographic subgroups also are provided.

Prior to additional analyses, basic assumptions of multiple linear regression modeling were tested and satisfied. G*Power 3.1 (Faul, Erdfelder, Lang, \& Buchner, 2007) was used to determine the probability of finding significant effects in the event they existed. For a moderate effect size $\left(f^{2}=.15\right)$ and a total sample size of 131 , the analysis yielded a power of .93 given $\alpha=.05$. To assess for multicollinearity and to test the hypothesis that student concentration, honors courses taken, AP courses taken, and high school GPA is positively correlated with first-semester college GPA, bivariate correlations and variance inflation factors (VIFs) were examined. As demonstrated in Table 2 , all variables, except concentration, were positively and significantly related to each other and college GPA $(p<.001)$. 
Table 1. Descriptive Statistics for College Grade Point Average (GPA), Race/Ethnicity, Gender, Family Structure, College Status, and Urbanicity

\begin{tabular}{|c|c|c|c|c|c|c|}
\hline $\begin{array}{l}\text { Criterion and Predictor } \\
\text { Variable }\end{array}$ & $N$ & $M$ & $S D$ & Min & $\operatorname{Max}$ & $p$ \\
\hline \multicolumn{7}{|l|}{ College GPA } \\
\hline Race/ethnicity & 131 & 2.85 & 0.82 & 0.78 & 4.0 & $<.05$ \\
\hline Minority & 87 & 2.72 & 0.86 & 0.78 & 4.0 & \\
\hline Majority (ref.) & 44 & 3.12 & 0.65 & 1.32 & 4.0 & \\
\hline Gender & 131 & 2.85 & 0.82 & 0.78 & 4.0 & $>.05$ \\
\hline Male & 34 & 2.67 & 0.84 & 0.89 & 4.0 & \\
\hline Female (ref.) & 97 & 2.92 & 0.81 & 0.78 & 4.0 & \\
\hline Family structure & 131 & 2.85 & 0.82 & 0.78 & 4.0 & $<.05$ \\
\hline Nontraditional & 62 & 2.64 & 0.80 & 0.81 & 3.9 & \\
\hline Traditional (ref.) & 69 & 3.04 & 0.79 & 0.78 & 4.0 & \\
\hline College status & 131 & 2.85 & 0.82 & 0.78 & 4.0 & $<.05$ \\
\hline First-generation & 76 & 2.67 & 0.85 & 0.78 & 4.0 & \\
\hline Continuing-generation (ref.) & 55 & 3.11 & 0.71 & 0.87 & 4.0 & \\
\hline Urbanicity & 131 & 2.85 & 0.82 & 0.78 & 4.0 & $>.05$ \\
\hline Rural & 50 & 2.84 & 0.87 & 0.78 & 4.0 & \\
\hline Urban (ref.) & 81 & 2.86 & 0.79 & 0.87 & 4.0 & \\
\hline
\end{tabular}

Note. ref. $=$ reference category.

Table 2. Correlations and Variance Inflation Factors (VIFs) for Predictor and Criterion Variables

\begin{tabular}{lllllll} 
Variable & $\mathbf{1}$ & $\mathbf{2}$ & $\mathbf{3}$ & $\mathbf{4}$ & $\mathbf{5}$ & VIF \\
\hline 1. Concentration & - & .10 & .02 & .16 & .12 & 1.03 \\
2. Honors (5 or more) & & - & $.43^{*}$ & $.48^{*}$ & $.37^{*}$ & 1.43 \\
3. Advanced Placement & & & - & $.38^{*}$ & $.33^{*}$ & 1.29 \\
(1 or more) & & & & & & \\
4. High school GPA & & & & - & $.57^{*}$ & 1.38 \\
5. College GPA & & & & & - & \\
\hline
\end{tabular}

Note. GPA = grade point average.

${ }^{*} p<.001$.

\section{Main Analysis}

A four-step hierarchical multiple linear regression analysis was used to test the hypothesis that race/ethnicity, gender, family structure, college status, and urbanicity are correlated with firstsemester college GPA (see Table 3). This analysis also aimed to test the hypothesis that after race/ethnicity, gender, family structure, college status, and urbanicity are controlled, high school GPA and the number of honors and AP courses taken will positively correlate with college freshman GPA. Demographic variables were included in first step of the analysis. The variables were arranged by proximity (individual to system) and causal relationship (Petrocelli, 2003). As such, the order of variables in Step 1 was race/ethnicity (dummy coded; racial ethnic majority as reference), gender (dummy coded; female as reference), family structure (dummy coded; intact family unity as reference), college status (dummy coded; CGCS as reference), and urbanicity (dummy coded; metro 
as reference). These variables were included in the analysis due to findings from prior research that suggested their relationship with college GPA.

Table 3. Summary of Hierarchical Regression Analysis for Variables Predicting College Grade Point Average (GPA)

\begin{tabular}{|c|c|c|c|c|c|}
\hline Predictor Variable & $B$ & $S E B$ & $\beta$ & $R^{2}$ & $\Delta \boldsymbol{R}^{2}$ \\
\hline Step 1 & & & & .17 & .17 \\
\hline Race/ethnicity & -0.28 & 0.15 & -.16 & & \\
\hline Gender & -0.29 & 0.15 & -.16 & & \\
\hline Family structure & -0.34 & 0.14 & $-.21^{*}$ & & \\
\hline College status & -0.38 & 0.14 & $-.23^{* *}$ & & \\
\hline Urbanicity & -0.05 & 0.14 & -.03 & & \\
\hline Constant & 3.51 & 0.16 & & & \\
\hline Step 2 & & & & .27 & .10 \\
\hline Race/ethnicity & -0.25 & 0.14 & -.15 & & \\
\hline Gender & -0.24 & 0.15 & -.13 & & \\
\hline Family structure & -0.28 & 0.13 & $-.17^{*}$ & & \\
\hline College status & -0.35 & 0.13 & $-.21^{* *}$ & & \\
\hline Urbanicity & -0.14 & 0.13 & -.09 & & \\
\hline Honors courses ( 5 or more) & 0.55 & 0.14 & $.32 * * *$ & & \\
\hline Constant & 3.10 & 0.18 & & & \\
\hline Step 3 & & & & .29 & .03 \\
\hline Race/ethnicity & -0.24 & 0.14 & -.14 & & \\
\hline Gender & -0.22 & 0.14 & -.12 & & \\
\hline Family structure & -0.25 & 0.13 & $-.16^{*}$ & & \\
\hline College status & -0.35 & 0.13 & $-.21^{* *}$ & & \\
\hline Urbanicity & -0.13 & 0.13 & -.08 & & \\
\hline Honors courses ( 5 or more) & 0.43 & 0.15 & $.25^{* *}$ & & \\
\hline AP course ( 1 or more) & 0.29 & 0.14 & $.18^{*}$ & & \\
\hline Constant & 2.99 & 0.18 & & & \\
\hline Step 4 & & & & .39 & .10 \\
\hline Race/ethnicity & -0.16 & 0.13 & -.09 & & \\
\hline Gender & -0.14 & 0.14 & -.08 & & \\
\hline Family structure & -0.15 & 0.12 & -.09 & & \\
\hline College status & -0.21 & 0.13 & -.13 & & \\
\hline Urbanicity & -0.11 & 0.12 & -.07 & & \\
\hline Honors course ( 5 or more) & 0.19 & 0.15 & .11 & & \\
\hline AP course ( 1 or more) & 0.17 & 0.13 & .11 & & \\
\hline High school GPA & 0.46 & 0.11 & $.40 * * *$ & & \\
\hline Constant & 1.39 & 0.40 & & & \\
\hline
\end{tabular}

Note. $\mathrm{AP}=$ Advanced Placement.

${ }^{*} p<.05 .{ }^{* *} p<.01 .{ }^{* * *} p<.001$.

In Step 1 of the hierarchical multiple linear regression, a significant relationship between the predictor variables and college GPA was found, $F(5,125)=5.20, p<.001, R^{2}=.17$ (adjusted $R^{2}=$ .14). Specifically, the combination of these five variables accounted for $17 \%$ of the variance explained in first-semester college GPA. Family structure $(B=-.21)$ and college status $(B=-.23)$ significantly contributed to the model. In Step 2, the predictor variable five or more honors courses, in combination with race/ethnicity, gender, family structure, college status, and urbanicity, was significantly correlated with first-semester college GPA, $F(6,124)=7.55, p<.001, R^{2}=.27$ (adjusted $\left.R^{2}=.23\right)$. Five or more honors courses increased the variance explained in first-semester college GPA by $10 \%$. In Step 3, race/ethnicity, gender, family structure, college status, urbanicity, five or more honors courses, and one or more AP courses in combination were significantly related to first- 
semester college GPA, $F(7,123)=7.26, p<.001, R^{2}=.29$ (adjusted $\left.R^{2}=.25\right)$. AP course enrollment accounted for the variance explained in first-semester college GPA by 3\%. In Step 4, high school GPA was added to the model to explore the degree to which this predictor variable increased the amount of explained variance in first-semester college GPA. The addition of high school GPA in the model resulted in an increase in variance explained by $10 \%$. The linear combination of the predictor variables in step four explained a significant amount of the variance in first-semester college GPA, $F(8,122)=9.76, p<.001, R^{2}=.39$ (adjusted $R^{2}=.35$ ). In sum, the demographic variables included in this study, in addition to 5 or more honors courses, AP course enrollment, and high school GPA are significant predictors individually and in combination based on Cohen's (1992) assertion that $\Delta R^{2} \geq$ .02 indicates distinct contributions to the variance explained in a model.

\section{Discussion}

The purpose of this study was to evaluate the impact of student demographics, high school course enrollment patterns, and high school GPA on first-semester college GPA. The initial analysis indicated that the completion of five or more honors courses and the completion of one or more AP courses in high school are positively associated with first-semester college GPA. Additionally, high school GPA was positively related to first-semester college GPA. While concentration is not predictive of first-semester college GPA, these findings partially supported Hypothesis 1 . As supported by prior research, these findings indicate that students who complete rigorous course work in high school are better positioned for initial academic success in college (Barnett, 2018; Castellano et al., 2014; Goins, 2016; Pretlow \& Wathington, 2014). Additionally, the higher a student's high school GPA, the higher their first-semester college GPA. These preliminary findings highlight the critical role high school academic preparation and success play in the outcomes of students in college, at least initially.

The findings of the main analysis partially supported Hypothesis 2. Family structure and college status were related to first-semester college GPA. First-semester college students from single parent homes or those who lived with relatives (e.g., grandparents, uncles) reported lower first-semester college GPAs than their peers from intact, traditional or nuclear families. This finding is consistent with research conducted by El Nokali, Bachman, and Votruba-Drzal (2010) and Jeynes (2005). Parents play a critical role in the educational outcomes of their children. Parents who have obtained postsecondary degrees appear to provide their children with the apropos support needed for postsecondary success. This study indicated that first-semester college GPA was higher for students with parents who earned an associate degree or higher. Similarly, Holmes and Slate (2017) noted that college GPAs were higher for CGCS when compared to FGCS. While the quantity of support provided by parents of CGCS and FGCS is comparable, parents of CGCS appear positioned to offer more relevant and quality support (Palbusa \& Gauvain, 2017). It is important FGCS are provided with equitable support and resources during their transition from high school to college.

Urban high schools are often better resourced and offer more rigorous courses (i.e., honors, AP courses) than rural schools according to a report on rural education by Lavalley (2018). As a result, students who attend urban schools have the opportunity to engage in more rigorous course work and, thus, likely better prepared for the academic demands of college. However, this effect was not apparent in the current study. In addition to urbanicity, neither race/ethnicity nor gender was significantly related to first-semester college GPA. These finding suggest that parental education and family structure are far better indicators of first-semester college GPA. However, given the way urbanicity and race/ethnicity were analyzed, these finds should be considered with caution. It is possible that these variables are related to first-semester college GPA if they were disaggregated or coded differently. When combined, race/ethnicity, gender, family structure, college status, and urbanicity account for a significant amount of variance explained in college GPA, more than honors courses, AP courses, or high school GPA alone. As such, it appears that a variety of demographic 
variables, rather than any single secondary education experience, remains a better predictor of postsecondary success.

Relative to Hypothesis 3, results of this study indicate that students who complete five or more honors courses in high school are more likely to have a higher first-semester college GPA than students who took fewer than five honors courses. When race/ethnicity, gender, family structure, college status, and urbanicity are controlled, completing five or more honors courses is significantly related with first-semester college GPA. This finding suggests that when students are challenged by rigorous high school coursework, they are better prepared for the course load and academic demands of their first semester of college. Consistent with previous research, students who complete a challenging or rigorous curriculum in high school were more successful in college (Klopfenstein \& Lively, 2012; Klopfenstein \& Thomas, 2009).

Regarding AP course enrollment, after demographic variables and honors course completion are controlled, a significant positive relationship existed between students who completed at least one AP course and their first-semester college GPA. This finding is consistent with the relationships found between AP course enrollment and postsecondary success in previous research (Patterson, Packman, \& Kobrin, 2011; Sadler, Sonnert, Tai, \& Klopfenstein, 2010). It is plausible that these courses, especially honors courses, help to prepare students for the rigor of college courses. Alternatively, students who take five or more honors courses and more than one AP course are likely positioned with the ability and support required for successful completion of more rigorous courses and will naturally excel in their postsecondary endeavors, as research conducted by Klopfenstein and Thomas (2009) suggested. Should school systems expand AP and honor course offerings in an effort better prepare students for college, they are encouraged to do so judiciously and consider the implications and unintended consequences.

Finally, concerning high school GPA, it is a significant predictor of first-semester college GPA when demographics, honors courses, and AP courses are controlled. Students who graduate from high school with high GPAs are likely to have high GPAs at the end of their first semester in college, based on the findings of this study. This study supports previous research that suggested high school GPA is a predictor of college GPA (Hodara \& Lewis, 2017; Kobrin \& Michel, 2006; Mould \& DeLoach, 2017). Similarly, Hodara and Lewis (2017) found among recent graduates that regardless of whether a student resided in a rural or urban area, "high school grade point average was consistently predictive of college performance" (p. 5). While high school GPA is considered a distal measure of student success comprising myriad proximal academic achievements, it represents a student's body of work in high school and remains a solid indicator of their college performance. In sum, the findings of this study partially support Hypothesis 3. When demographics variables are controlled, honors courses, and AP courses are significantly related to first-semester college GPA accounting for $13 \%$ of the variances explained. However, the variance explained by these variables is absorbed by high school GPA, further demonstrating the strength of its relationship with first-semester college GPA.

\section{Limitations}

This study offers insight into demographic and high school variables that predict first-semester college GPA. However, when considering the findings, it is important to note several limitations. First, data were collected through measures that required self-reporting. As such, it is possible that participants did not accurately respond to some of the items on the survey. For example, participants may have provided socially desirable responses to demographic questions (i.e., parent education) or items related to GPA. Additionally, the participants were part of a convenience sample; all were freshmen enrolled at the same university where both researchers were employed. It is also important to note that the sample is representative of first-semester students who persisted through their 
freshmen year. However, the study does not include students who dropped out after the first semester, therefore the findings may not be representative of all students' high school and college academic experiences who were admitted for the academic year under investigation. Finally, the sample is representative of students enrolled in an MSI who persisted to their second semester. However given the unique history of MSIs, researchers should use caution when generalizing the findings to other MSIs or predominantly White institutions.

\section{Future Research}

While this article sheds light on key factors that predict first-semester college GPA, additional research is required. First, it is important to further explore the impact of demographic factors on first-semester college success. A replication of the current study using a larger sample will allow for the disaggregation of demographic data in a more distinct manner. As such, researchers can attempt to better understand the nuances of data from specific demographic subsets (i.e., African American, American Indian) of the college going population. Similarly, researchers should further explore and identify aspects of AP and honor courses that are central to college success. By pinpointing conditions of these courses that readily contribute to college preparation, educators can modify or adapt less rigorous coursework to include key components that enhance CCR. Future research exploring predictors of first-semester college GPA also should include students who did not persist beyond the first semester. While absent from this study, this group of students may offer additional insight into the high school to college transition and college retention efforts. Finally, researchers are encouraged to conduct longitudinal studies that track students from middle school to college to better understand the impact of $\mathrm{K}-12$ academic experiences on persistence and retention beyond the first semester of college.

\section{Implications}

The findings of this study offer implications that span K-12 schools to college. K-12 and college educators are encouraged to develop targeted programming that supports the academic efforts of all students, especially those from nontraditional families as well as students whose parents have limited educational experiences. It is critical that intentional consideration for strategies and interventions that meet the unique needs of subsets of the student body are developed as opposed to a "one size fits all" approach. Demographic risk factors associated with low first-semester college GPA must be considered when working with students to promote postsecondary success.

Educational stakeholders should consider the findings of this study within the context of the larger body of research on high school factors that impact college student success. For example, O'Malley, Voight, Renshaw, and Eklund (2015) suggested the impact of nontraditional family structures on GPA dissipates with positive perceptions of school climate. Therefore, high schools and universities should consider exploring student perceptions of campus climate, especially those from nontraditional family units. School counselors as well as student support services personnel on college campuses can survey students or conduct focus groups to better understand their perceptions of the campus climate. This data can serve as a basis for the development of strategies that foster optimal learning environments, positive school climate, and promotes academic success. In some instances, slight modifications to school climate can position students from nontraditional families for college success.

Additionally, Palbusa and Gauvain (2017) suggested that FGCS often do not receive the necessary type of support from their parents for success in college. This claim, in conjunction with the findings of this study, suggest it is important K-12 schools offer students whose parents have not earned a college degree additional support that extend beyond that afforded to students whose parents have completed an associate degree or higher. Additional support may include mentorship, peer 
assistance, enrollment in summer camps focused on college opportunities, or additional contact hours with the school counselor. School administrators are encouraged to provide ample opportunities for student to access these resources.

School administrators are encouraged to focus on increasing academic rigor across the K-8 curriculum to better prepare students for participation in advanced high school courses. In addition to offering academic support, school counselors also can work to develop social-emotional skills, such as resilience and grit, noncognitive skills that can prove useful as students transition to postsecondary education (Warren \& Hale, in press). Given the rigor of advanced-level high school courses, learning how to manage stress, persevere, and overcome obstacles are invaluable skills for students that can have a direct impact on GPA (Yeager et al., 2019).

High school administrators as well as school counselors are advised to ensure policies and procedures are in place for the effective and efficient identification and enrollment of students who qualify for placement in honors and AP courses. Since the findings of this study suggest that enrollment in five or more honors courses and at least one AP course are gateways to first-semester college success, schools should ensure that all qualified students have the opportunity and are encouraged to enroll in these courses. Despite recent efforts to close the achievement gap, Theokas and Saaris (2013) found a continuous gap in opportunity for AP course participation among students from lower income households. Establishing student profiles that contain relevant demographic information may be helpful as schools identify and support students' efforts to position themselves for college. Monitoring of students' grades also should occur with mechanisms in place to support students enrolled in these courses.

The relationship between high school GPA and college GPA is evident. Those who succeed in high school, tend to succeed in college. State-level as well as school system and K-12 school leaders are encouraged to consider the ramifications of educational outcomes such as retention, failure, suspension, and educational engagement on GPA, as noted by Warren, Locklear, and Watson (2018). State education boards should ensure CCR and CCS policies are adequately designed to prepare all high school students for college. Similarly, school system leaders are challenged to provide all students with equitable policies, opportunities, and resources beginning in Kindergarten and throughout high school. Academic success is attainable by all students when the appropriate guidance, support, and policies are in place. Therefore, it is critical educational leaders analyze school-wide disaggregated student achievement data to identify potential barriers to K-12 success. Through data-driven decision making, school systems and states can address educational inequities and establish nurturing educational environments where all students can succeed. Additionally, school administrators must cultivate high expectations among teachers, parents, and students beginning in elementary school. Maintenance of these expectations is critical as students matriculate to middle and high school because "academic achievement by 8th grade is one of the largest predictors of college readiness" (Executive Office of the President, 2014, p. 6). Doing so will best position students for academic success, equipping them with the tools and support necessary to manage the rigor of honor and AP courses and maintain a high GPA, keys to first-semester college success.

Finally, colleges also are encouraged to explore strategies to support students as they transition from high school to college. For example, colleges can scaffold course rigor for students who enrolled in less than five honors courses in high school. This measure may afford students the opportunity to succeed in initial courses while gaining the prerequisite skills needed for the demands of future coursework. Additionally, colleges and universities are challenged to partner with local middle and high schools through grant and service-based initiatives to support efforts to increase course rigor and prepare students for postsecondary education. Middle-/high-school-college mentoring programs may be a viable option for supporting students with limited exposure to rigorous secondary 
coursework. It is possible that greater collaboration between high schools and colleges can offset the impact of less rigorous high school course enrollment on first-semester college GPA.

\section{Conclusion}

High school factors including AP and honors course enrollment, as well as high school GPA, appear to predict first-semester college GPA. Parents' education level and family structure also impact college success. While this study does have limitations, the findings contribute to existent literature related to postsecondary student success. Public schools and colleges are both responsible for the postsecondary outcomes of students. As such, it is vital that school administrators and counselors as well as university instructors and academic support staff consider the findings of this study.

Researchers also are challenged to build upon these findings and develop collaborative interventions that promote high school-college success. By exploring strategies that minimize risk factors and offer students opportunities that equip them for the demands of college coursework, K-12 schools and college can ensure that all students have the opportunity to succeed during their first semester of college.

\section{References}

ACT. (2016). National curriculum survey 2016. Education and work in a time of change. Retrieved from https://www.act.org/content/dam/act/unsecured/documents /NCS_Policy_Report.pdf

Barnett, E. (2018). Differentiated dual enrollment and other collegiate experiences: Lessons from the STEM early college expansion partnership. New York, NY: Community College Research Center, Teachers College, Columbia University. Retrieved from https://jfforg-prodprime.s3.amazonaws.com/media/documents/Differential-Dual-Enrollment-030518.pdf

Brand, B., Browning, A., \& Valent, A. (2013). How career and technical education can help students be college and career ready: A primer. Washington, DC: American Institutes for Research. Retrieved from http://www.aypf.org/wp-content/uploads/2013/04/CCRS-CTE-Primer-2013.pdf

Castellano, M., Sundell, K. E., Overman, L. T., Richardson, G. B., \& Stone, J. R. III. (2014, April). Rigorous tests of student outcomes in CTE programs of study: Final report. Louisville, KY: National Research Center for Career and Technical Education. Retrieved from http://www.nrccte.org/sites/default/files/publicationfiles/nrccte_cte_programs_of_study_career_pathways.pdf

Challenge Success. (2013). The advanced placement program: Living up to its promise? Retrieved from http://www.challengesuccess.org/wp-content/uploads/2016/11/ChallengeSuccessAdvancedPlacement-WP.pdf

Cohen, J. (1992). A power primer. Psychological Bulletin, 112, 155-159. doi:10.1037/00332909.112.1.155

College Board. (2017). AP program participation and performance data 2017. Retrieved from https://research.collegeboard.org/programs/ap/data/participation/ap-2017

College Board. (2018). Preparing students for college. Retrieved from https://professionals.collegeboard.org/guidance/prepare/honors-ap

El Nokali, N. E., Bachman, H. J., \& Votruba-Drzal, E. (2010). Parent involvement and children's academic and social development in elementary school. Child Development, 81, 988-1005. doi:10.1111/j.1467-8624.2010.01447.x

Executive Office of the President. (2014). Increasing college opportunity for low-income students: Promising models and a call to action (Obama Administration). Retrieved from 
https://obamawhitehouse.archives.gov/sites/default/files/docs/increasing_college_opportunity_ for_low-income_students_report.pdf

Faul, F., Erdfelder, E., Lang, A. G., \& Buchner, A. (2007). G*Power 3: A flexible statistical power analysis program for the social, behavioral, and biomedical sciences. Behavior Research Methods, 39, 175-191. doi:10.3758/BF03193146

Floyd, L. S. (2014). Impact of career and technical education on college and career readiness in Kentucky (Doctoral dissertation). Online Theses and Dissertations, 260. Retrieved from https://encompass.eku.edu/etd/260

Goins, C. (2016). A phenomenological study examining the experiences of high school graduates who participated in a career and technical education program of study (Doctoral dissertation). Doctoral Dissertations and Projects. 1133. Retrieved from https://digitalcommons.liberty.edu/doctoral/1133/

Hodara, M., \& Lewis, K. (2017). How well does high school grade point average predict college performance by student urbanicity and timing of college entry? (REL 2017-250). Washington, DC: U.S. Department of Education, Institute of Education Sciences, National Center for Education Evaluation and Regional Assistance, Regional Educational Laboratory Northwest.

Holles, C. E. (2016). Student perceptions of preparedness for college: A case study of students in a first-year required course. Curriculum and Teaching Dialogue, 18, 119-137.

Holmes, D. L., \& Slate, J. R. (2017). Differences in GPA by gender and ethnicity/race as a function of first-generation status for community college students. Global Journal of Human-Social Science Research, 17, 1-5.

Ivers, N. N., Johnson, D. A., Clarke, P. B., Newsome, D. W., \& Berry, R. A. (2016). The relationship between mindfulness and multicultural counseling competence. Journal of Counseling \& Development, 94, 72-82. doi:10.1002/jcad.12063

Jeynes, W. H. (2005). Effects of parent involvement and family structure on the academic achievement of adolescents. Marriage \& Family Review, 37, 99-116. doi:10.1300/J002v37n03_06

Jimenez, L., Morales, J., Sargrad, S., \& Thompson, M. (2016). Remedial education: The cost of catching up. Retrieved from https://cdn.americanprogress.org/content/uploads/2016/09/29120411/CostOfCatchingUp2reportINTRO.pdf

Klopfenstein, K., \& Lively, K. (2012). Dual enrollment in the broader context of college-level high school programs. New Directions for Higher Education, 158, 59-68. doi:10.1002/he.20015

Klopfenstein, K., \& Thomas, M. K. (2009). The link between advanced placement experience and early college success. Southern Economic Journal, 75(3), 873-891.

Kobrin, J. L., \& Michel, R. S. (2006). The SAT® as a predictor of different levels of college performance: Research Report, No. 2006-3. New York, NY: College Board. Retrieved from https://files.eric.ed.gov/fulltext/ED563073.pdf

Kolluri, S. (2018). Advanced placement: The dual challenge of equal access and effectiveness. Review of Educational Research, 88, 671-711. doi:10.3102/0034654318787268

Lavalley, M. (2018). Out of the loop: Rural schools are largely left out of research and policy discussions, exacerbating poverty, inequity, and isolation. Retrieved from https://education.wsu.edu/documents/2018/12/center-public-education-rural-schoolsreport.pdf 
Lewis, M. V., Kosine, N. R., \& Overman, L. (2008). What will be the impact of programs of study? A preliminary assessment based on similar previous initiatives, state plans for implementation, and career development theory. Louisville, KY: National Research Center for Career and Technical Education, University of Louisville.

Meeder, H., \& Suddreth, T. (2012). Common core state standards \& career and technical education: Bridging the divide between college and career readiness. Retrieved from http://www.achieve.org/CCSS-CTE-BridgingtheDivide

Mould, T., \& DeLoach, S. B. (2017). Moving beyond GPA: Alternative measures of success and predictive factors in honors programs. Journal of the National Collegiate Honors Council Online Archive 18, 552. Retrieved from http://digitalcommons.unl.edu/nchcjournal/552

O'Malley, M., Voight, A., Renshaw, T. L., \& Eklund, K. (2015). School climate, family structure, and academic achievement: A study of moderation effects. School Psychology Quarterly, 30, 142157. doi:10.1037/spq0000076

Palbusa, J. A., \& Gauvain, M. (2017). Parent-student communication about college and freshman grades in first-generation and non-first-generation students. Journal of College Student Development, 58, 107-112. doi:10.1353/csd.2017.0007

Patterson, B. F., Packman, S., \& Kobrin, J. L. (2011). Advanced Placement exam-taking and performance: Relationships with first-year subject area college grades. New York, NY: College Board.

Petrocelli, J. V. (2003). Hierarchical multiple regression in counseling research: Common problems and possible remedies. Measurement and evaluation in counseling and development, 36, 922 .

Pretlow, J., \& Wathington, H. D. (2014). Expanding dual enrollment: Increasing postsecondary access for all? Community College Review, 42, 41-54. doi:10.1177/0091552113509664

Reed, E., \& Justice, M. (2014). College and high school educators' perceptions of current college readiness levels. International Journal of Humanities and Social Science, 4, 37-44.

Rothwell, J. (2016). Defining skills technical work. Issues of Science and Technology, 33, 47-51.

Sadler, P. M., Sonnert, G., Tai, R. H., \& Klopfenstein, K. (2010). AP: A Critical examination of the advanced placement program. Cambridge, MA: Harvard Education Press.

Theokas, C., \& Saaris, R. (2013). Finding America's missing AP and IB students. Washington DC: The Education Trust. Retrieved from https://edtrust.org/resource/finding-americas-missingap-and-ib-students/

U.S. Department of Agriculture. (2013). Rural-urban continuum codes. Retrieved from https://www.ers.usda.gov/data-products/rural-urban-continuum-codes/

U.S. Department of Education. (2015). Every student succeeds act. Retrieved from https://www.ed.gov/essa

U.S. Department of Education, Office of Planning, Evaluation and Policy Development Policy and Program Studies. (2017). Issue brief: College-level coursework for high school students. Retrieved from https://www2.ed.gov/rschstat/eval/high-school/college-level-coursework.pdf

U.S. Department of Education, Office of Vocational and Adult Education. (2012). Investing in America's future: A blueprint for transforming career and technical education. Retrieved from https://www2.ed.gov/about/offices/list/ovae/pi/cte/transforming-career-technical-education.pdf

Warren, J. M., \& Hale, R. W. (in press). Predicting grit and resilience: Exploring college students' academic rational beliefs. Journal of College Counseling. 
Warren, J. M., Locklear, L., \& Watson, N. (2018). The role of parenting in predicting student achievement: Considerations for school counseling practice and research. The Professional Counselor, 8, 328-340. doi:10.15241/jmw.8.4.328

Weinstein, P. (2016). Diminishing credit: How colleges and universities restrict the use of advanced placement. Washington, DC: Progressive Policy Institute. Retrieved from http://www.progressivepolicy.org/wp-content/uploads/2016/09/MEMO-Weinstein-AP.pdf

Woods, C. S., Park, T., Hu, S., \& Betrand Jones, T. (2018). How high school coursework predicts introductory college-level course success. Community College Review, 46, 176-196. doi:10.1177/0091552118759419

Yeager, D. S., Hanselman, P., Walton, G. M., Murray, J. S., Crosnoe, R., Muller, C., ... Dweck, C. S. (2019). A national experiment reveals where a growth mindset improves achievement. Nature, 573, 364-369. doi:10.1038/s41586-019-1466-y

The Journal of Educational Research and Practice provides a forum for studies and dialogue that allows readers to better develop social change in the field of education and learning. Journal content may focus on educational issues of all ages and in all settings. It also presents peer-reviewed commentaries, book reviews, interviews of prominent individuals, and additional content. The objectives: We publish research and related content that examines current relevant educational issues and processes aimed at presenting readers with knowledge and showing how that knowledge can be used to impact social change in educational or learning environments. Additional content provides an opportunity for scholarly and professional dialogue regarding that content's usefulness in expanding the body of scholarly knowledge and increasing readers' effectiveness as educators. The journal also focuses on facilitating the activities of both researcher-practitioners and practitioner-researchers, providing optimal opportunities for interdisciplinary and collaborative thought through blogging and other communications. Walden University Publishing:

http://www.publishing.waldenu.edu 